\title{
Blood Serum Affects Polysaccharide Production and Surface Protein Expression in S. Aureus
}

\author{
Nazrul Islam ${ }^{1 *}$, Khwaja G. Hossain ${ }^{2}$, Julia M Ross ${ }^{3}$ and Mark R Marten ${ }^{3}$ \\ ${ }^{1}$ Department of Nutrition and Food Science, University of Maryland-College Park, USA \\ ${ }^{2}$ Mayville State University, USA \\ ${ }^{3}$ Department of Chemical, Biochemical and Environmental Engineering, University of Maryland Baltimore County (UMBC), USA
}

Submission: February 01, 2017; Published: March 03, 2017

Abstract

Background: S. aureus biofilm serves a major role in pathogenesis. Two of the major components of bacterial biofilm are Polysaccharides intercellular adhesions (PIA) and surface proteins. It is not known how PIA and surface proteins expressions are affected in presence of blood serum. Analyses of surface proteins expressions will provide more effective biomarker discovery that might lead to development of antimicrobial therapeutics to meet the challenges of biofilm-related infections.

Method: Secondary cultures of $S$. aureus Philips, a biofilm-forming bacterium, were generated by inoculating $1 \mathrm{ml}$ of overnight culture into $50 \mathrm{ml}$ of TSB. Bacteria were cultured at several concentrations of blood serum and found that $12.5 \%$ supplemented blood serum provide s similar growth curve as normal TSB (100\%). One and 2 D SASPAGE were used to separate proteins and the differentially expressed proteins were identified by nano-LC/MS.

Results: Polysaccharide intercellular adhesions production was significantly increased due to the addition of blood serum in the media. We also identified two serum proteins, apolipoprotein and globulin (Fc and Fab), that remained attached with the membrane fraction of bacterial proteins.

Conclusion: These results have strongly demonstrated that blood serum influences the exopolysaccharide expression in S. aureus.

Keywords: Biofilm; Serum; Staphylococcus aureus; Proteome

\section{Background}

A biofilms are micro Colonies of bacteria adhere to each other and to biotic or biotic surfaces, embedded in an extracellular matrix produced by the sessile bacterial cells [1]. Extracellular matrix (ECM) and ECM proteins in bacterial biofilm play crucial roles in contaminating the agricultural produce starting from the field to the packing. In addition, ECM mediates adhesions protect bacteria from external threats and other stressors of adverse environment. Some of the ECM enzymes hydrolyze macro biomolecules into smaller biomolecules which subsequently is taken up by bacteria [2,3].

Both polysaccharide and protein embedded in extracellular matrix of biofilm play critical roles in biofilm stability MartínCereceda et al. (2001); Tsuneda et al. (2003). The polysaccharide intercellular adhesns are the major components (90\%) of biofilm. Gutberlet et al. (1997); Gross et al. (2001); Weidenmaier \& Peschel (2008); Rupp et al. (1995) [4]. Two types of PIA have been reported based on structure,. PIA type I (typically>80\%) is a unique linear beta- 1,6 glucosaminoglycan which is predominantly positively charged. PIA type II (typically<20\%) is structurally similar to type I, but contains phosphate and ester-linked succinate, and thus carries a mild negative charge Rupp et al. (1995); Mack et al. (1996). The biofilms are stabilized by the linear structure of these PIAs electrostatic interaction between positively and negatively charged residues Mack et al. (1996). In addition, surface proteins appear to play a critical role in contributing to biofilm stability. For example, nearly all S. aureus clinical isolates possess and express the genes necessary for PIA production (ica-operon, described below), yet many do not form biofilms Fitzpatrick et al. (2005, 2006). This implies that surface proteins may act as additional biofilm stabilizers, possibly cooperating with PIA to mediate intercellular adhesion O'Gara (2007). 
In antibiotic therapy, biofilm has been found in $65-80 \%$ of the bacterial infections, and is considered refractory to host defenses [4]. Staphylococcus s. aureus, a biofilm forming bacteria, is responsible for severe skin infections to such major diseases as bacteremia, endocarditis and osteomyelitis. Under favorable conditions, S. aureus causes serious complications in devices like implants and catheters by producing biofilms on them [5]. Treatment of such infections becomes even more challenging given that several S. aureus strains show resistance to multiple antibiotics (e.g., methicilin and vancomycin). Extracellular matrix (ECM) proteins in bacterial biofilm play crucial roles in biofilm stability. In addition, ECM mediates adhesins to protect bacteria from external threats and also other stressors under adverse environment.

The mechanisms that how bacteria survive in their diverse natural habitats by using ECM and ECM proteins are yet to be fully understood. In a recent study, Floyd et al. [6] studied spatial proteome of surface-associated single-species biofilms formed by uropathogenic Escherichia coli and concluded the presence of at least two regulatory mechanisms controlling type 1 pili expression in response to oxygen availability. Similarly, a recent study on ECM proteome of Bacteroides fragilis, a widely distributed member of the human gut micro biome, identified several lipoproteins, TonB-dependent transporters and auto transporters [7]. Similar to theses investigations, several studies on ECM proteome in E coli were also performed [8-10]. Although these investigations have provided in-depth information about the certain ECM proteins, it is not known how surface proteins are affected in presence of serum. We, therefore, investigated how blood serum affects ECM and polysaccharide production and surface protein expression in S. aureus using proteomic techniques.

\section{Materials and Methods}

\section{Bacterial strain}

S. aureus Philips, a biofilm-forming bacterium, was used in this study. In previous studies, we successfully used this strain, which was originally isolated from a patient diagnosed with osteomyelitis Patti et al. (1994); George et al. (2006); George et al. (2007). Secondary cultures was generated by inoculating $1 \mathrm{ml}$ of overnight culture into $50 \mathrm{ml}$ of TSB and growing at 37 ${ }^{\circ} \mathrm{C}$ with constant rotation in shake flasks for 16 hours. We grew the bacteria at several concentrations of blood serum and found that $12.5 \%$ supplemented blood serum similar growth curve as normal TSB. The growth of the bacterial strains was monitored by measuring the absorbance of the broth at $600 \mathrm{~nm}$ on a spectrophotometer. The cells were then harvested and resuspended in phosphate-buffered saline (D-PBS; $138 \mathrm{~mm}$ $\mathrm{NaCl}, 2.7 \mathrm{mM} \mathrm{KCl}, \mathrm{pH}$ 7.4). Cell concentrations was be determined using a Coulter Multisizer.

\section{Measuring PIA}

The cell plate was created from one $\mathrm{ml}$ of the culture, transferred to a micro tube and centrifuged at 10,000xg for
10 min at $4{ }^{\circ} \mathrm{C}$. One $\mathrm{ml}$ of PBS buffer was used to wash the cell plates. Cells were then resuspended in $100 \mu$ of $0.5 \mathrm{M}$ EDTA, pH 8.0 and boiled in hot water for $10 \mathrm{~min}$ at $100{ }^{\circ} \mathrm{C}$. The sample was then centrifuged at $10,000 \mathrm{xg}$ for $10 \mathrm{~min}$ at $4^{\circ} \mathrm{C}$. The clear supernatant was transferred to a new micro tube. Boiling cells with $0.5 \mathrm{M}$ EDTA is the best method known to date for the isolation of crude PIA from staphylococcal cell surface [11]. The crude PIA quantification was performed by a colorimetric method as described elsewhere [12]. Briefly, $50 \mu \mathrm{l}$ of the crude PIA was transferred to a micro tube and mixed with $25 \mu \mathrm{l}$ of $80 \%$ w/v Phenol solution (Sigma-Aldrich) and $1 \mathrm{ml}$ of concentrated sulphuric acid was added. The solution was kept at room temperature for $10 \mathrm{~min}$, and absorbance was read at $490 \mathrm{~nm}$. Normalization of the amount of PIA was performed by dividing by the number of cells used for extraction.

\section{Protein extraction}

Cells were washed with PBS containing $0.1 \%$ sodium azide and then with PBS without azide, followed by a brief wash with digestion buffer containingm $10 \mathrm{~mm}$ Tris HCl, $1 \mathrm{~mm}$ EDTA, $5 \mathrm{~mm}$ $\mathrm{MgCl} 2$. Approximately $5 \times 109$ bacterial cells were resuspended in $1 \mathrm{ml}$ of digestion mixture containing $35 \%$ raffinose, protease inhibitor cocktail (1 tablet/ml of digestion buffer), lysostaphin (5units/ml) and then incubated at $37{ }^{\circ} \mathrm{C}$ for $30 \mathrm{~min}$. Cell debris were removed by centrifugation at $8,000 \mathrm{~g}$ for 20 minutes and the supernatant was collected. After digestion and centrifugation, the digest was kept at $-20{ }^{\circ} \mathrm{C}$ overnight and then centrifuged at $8,000 \mathrm{~g}$ for $20 \mathrm{~min}$ precipitated raffinose was discarded. After digestion and centrifugation, the protein solution was subjected to ultrafiltration using the Millipore ultrafiltration tube and centrifuged as per manufacturer's instructions. Protein concentration in the solution was determined using $2 \mathrm{D}$ Quant (GE) and the resulting solution will be stored at $-80{ }^{\circ} \mathrm{C}$ for 2 -DE.

\section{Two dimensional gel electrophoresis}

In preparation for 2-DE, $150 \mu \mathrm{g}$ proteins was resolubilized by adding standard sample solubilization buffers containing urea (8M), thiourea (2M), ASB $14(1 \%)$, DTT (1\%), and Carrier ampholytes $(0.08 \%)$. The resulting solution was diluted to the desired volume with destreak rehydration solutions. Rehydration of IPG strips with the sample was carried out in the Immobiline Dry Strip Re-swelling Tray (GE Healthcare) according to the manufacturer's instructions. IPG strips of pH 3-11 (NL $24 \mathrm{~cm}$ ) were used. The rehydrated strips were subjected to isoelectric focusing (IEF), performed using IPGphor operated at $20^{\circ} \mathrm{C}$ in gradient mode $(97 \mathrm{kVhr}$ ). After focusing, the strips were stored at $-80^{\circ} \mathrm{C}$ for later use. Prior to the second dimension SDS-PAGE, IPG strips were equilibrated for 15 minutes in equilibration solution (15 ml) containing 50mm Tris- $\mathrm{HCl}, \mathrm{pH} 8.8,6 \mathrm{M}$ urea, $30 \% \mathrm{w} / \mathrm{v}$ glycerol, $2 \% \mathrm{w} / \mathrm{v}$ SDS and traces of bromophenol blue with $100 \mathrm{mg} / 10 \mathrm{ml}(\mathrm{w} / \mathrm{v})$ of DTT.

A second equilibration was carried out for 15 minutes by adding iodoacetamide $(250 \mathrm{mg} / 10 \mathrm{ml})$ instead of DTT in equilibration solution. Second dimension vertical SDSPAGE 
was performed using large format $(26.8 \times 20.5 \mathrm{~cm})$ gels $(12.5 \%$ $\mathrm{T} / 2.6 \% \mathrm{C}$ ) according to the manufacturer's instructions. Electrophoresis was carried out with an initial constant voltage of $10 \mathrm{~mA} /$ gel applied for 30 minutes followed by $20 \mathrm{~mA} /$ gel for overnight until the bromophenol band exits the gel. The gels was stained with Colloidal Coomassie brilliant blue (BioRad). Gels were scanned as 12-bit TIFF images using Biorad GS-800 densitometer and analyzed by Nonlinear Dynamics Same Spots (v.3.2). Spot volumes were normalized by the software to a reference gel. At least three gels (biological replicates) for each treatment was used for analyses.

\section{Protein identification}

For mass spectrometric identification, gel spots were excised, destained, and digested with sequencing grade trypsin (Promega). Peptide samples were analyzed by Nano ESI-MS/ MS using LTQ (Finnigan, Thermo, USA). Nano LC was performed at reversed phase conditions using an Ultimate 3000 (Dionex corporation, USA) C18 column with a flow rate of 1-5 microliter/ min in $70-90 \%$ acetontrile containing $0.1 \%$ formic acid. MS and MS/MS data was collected and interrogated using SEQUEST against the NCBI non-redundant protein database for S. aureus providing peptide tolerance of $1.4 \mathrm{amu}$. Searched results were filtered using three criteria: distinct peptides, Xcorr vs Charge state $(1.50,2.00,2.50,3.00)$ and peptide probability $(0.001)$. The confirmation of the protein identification was based on the Xcorr value of more than 50 and Sf score for individual peptide of more than 0.8 .

\section{Results and Discussion}

\section{Blood serum affects polysaccharides intercellular adhesins}

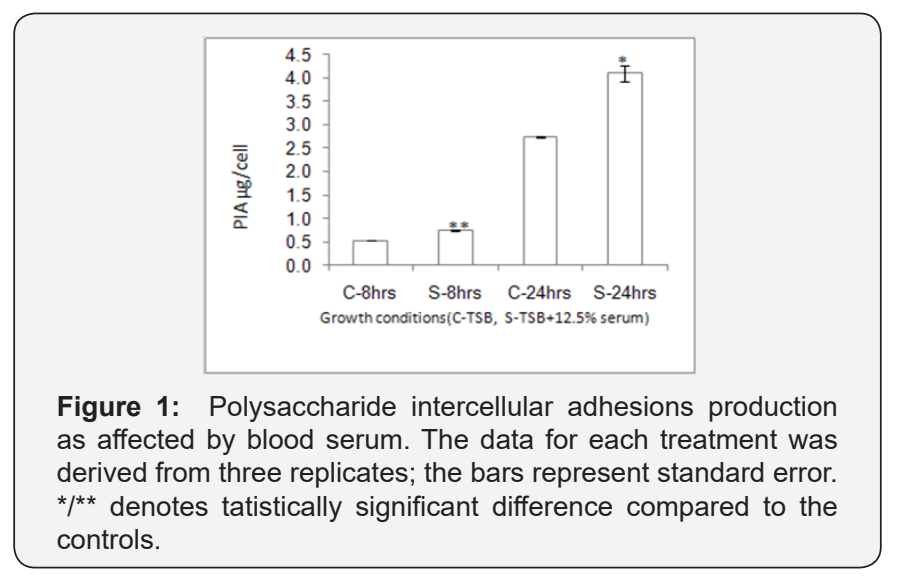

We have developed an experimental protocol for isolation and quantification of polysaccharides intercellular adhesins of S. aureus by boiling cells with 0.5M EDTA, digesting the PIA with concentrated sulphuric acid and phenol, and then measuring absorbance at $490 \mathrm{~nm}$. Although isolation of crude PIA by $0.5 \mathrm{M}$ EDTA is a routine procedure for PIA purification [13], to our knowledge it has not been reported for crude PIA quantification. We combined the EDTA extraction [13] with determination of sugars and their derivatives by colorimetry [11]. Using this procedure, we were able to reproducibly quantify PIA from S. aureus. As evident from the Figure 1, significantly higher amounts of PIA were observed in presence of blood serum. Similar to these findings, we also observed increased level of PIA in elevated level of $\mathrm{NaCl}$ [14].

PIA biosynthesis is mediated by ica operon-encoded enzymes $[15,16]$. The icaA, D and C gene products are involved in translocation of the growing polysaccharide to the cell surface [17], while IcaB is responsible for deacetylation of the PIA I molecule (providing its positive charge) which is essential for biofilm formation [18]. In contrast, the icaR gene, located upstream of the ica ADBC operon, encodes a transcriptional repressor which plays a central role in the environmental regulation of the ica operon [19]. For example, exposure to $\mathrm{NaCl}$ activates the ica operon in an icaR-dependant manner [18-20]. We anticipate that blood serum might have similar effect on the ica operon in an icaR-dependant manner, which is yet to be explored.

\section{Blood serum and fibronectin binding and collagen binding proteins}

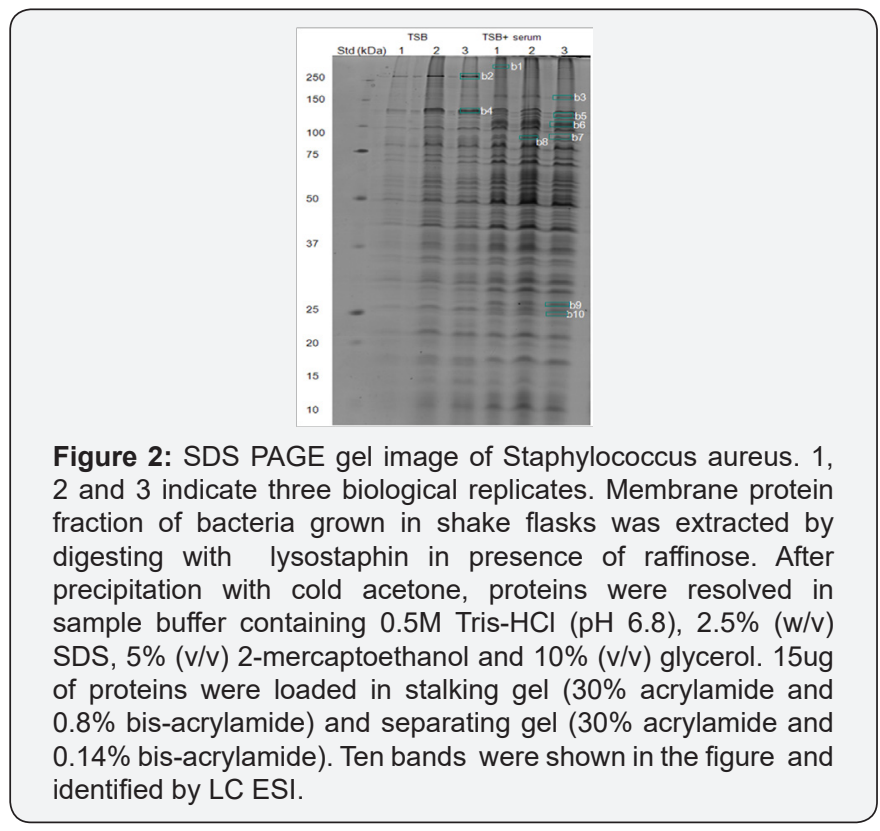

In the SDSPAGE (Figure 2) (Table 1), several virulenceassociated surface proteins were identified such as fibronectinbinding protein (b2), collagen-adhesins precursor (b4, b7), trigger factor (b8). However, serum supplement significantly reduced the abundance of fibronectin binding protein, although the abundance of collagen binding protein was not affected. In a recent report, Shinji H et al. (2011) studied, Fibronectin-binding protein A (FnBPA) and FnBPB, by constructing constructed fnbA and/or fnbB mutant strains and reported that the serum levels of interleukin- 6 and nuclear factor $\kappa \mathrm{B}(\mathrm{NF}-\kappa \mathrm{B})$ activation have no significant reduction in fnbB mutant infection(18)s. It is probable that the NF- $\kappa \mathrm{B}$ of serum we used might have reduced the fibronectin-binding protein. 


\section{Advances in Biotechnology \& Microbiology}

Table 1: Identification of proteins bands. Protein bands cut from the gels, digested by trypsin and identified via tandem mass spectrometry (MS).

\begin{tabular}{|c|c|c|c|c|}
\hline Band ID & Protein Name/Gene & Functional Category & plimw & Acce. No. \\
\hline $\mathrm{bl}$ & Apolipoprotein (Homosapien) & Encodes lipoprotein & $6 \_6 / 515$ & P04114 \\
\hline b2 & Fibronectin-binding protein (fnb) & Adhesin and anchor & $4 \_4 / 113$ & NP_373027 \\
\hline b3 & DNA-directed RNA polymerase(rpoB) & $\begin{array}{l}\text { Transcription of DNA } \\
\text { into RNA }\end{array}$ & $4 \_7 / 127$ & АВ 020472 \\
\hline \multirow[t]{2}{*}{ b4 } & 1. Aconitate hydratase (citB) & $\begin{array}{l}\text { Carbohydrate } \\
\text { metabolism }\end{array}$ & $43 / 98$ & NP_371274 \\
\hline & 2. Collagen adhesin precursor (MW2612) & Surface Adhesin & 5.81133 & NP_647429 \\
\hline \multirow[t]{3}{*}{ b5 } & 1. DNA-directed RNA polymerase(rpoB) & $\begin{array}{l}\text { Transcription of DNA } \\
\text { into RNA }\end{array}$ & $6 \_5 / 135$ & NP_371067 \\
\hline & 2.Pyruvate carboxylase (pycA) & $\begin{array}{l}\text { Carbohydrate } \\
\text { metabolism }\end{array}$ & 5_0/128 & NP_371638 \\
\hline & 3.1soleucyl-tRNA synthetase (ileS) & Aminio Acid biosynthesis & $5.2 / 104$ & NP_371717 \\
\hline \multirow[t]{3}{*}{ b6 } & 1. Alanyl-tRNA synthetase & RNA synthesis & $4.9 / 93$ & NP_372142 \\
\hline & 2. Hypothetical protein (SAV0219) & Not known & $4.6 / 37$ & NP_370743 \\
\hline & 3.Collagen adhesin precursor (MW2612) & Surface Adhesin & 5.81132 & NP_647429 \\
\hline \multirow[t]{3}{*}{ b7 } & 1 Alpha-keto acid dehydrogenase (pdhc) & $\begin{array}{l}\text { Carbohydrate } \\
\text { metabolism }\end{array}$ & $4.8 / 46$ & NP_371619 \\
\hline & 2. Preprotein translocase $(\sec A)$ & Protein export & $5 \_0 / 46$ & NP_371277 \\
\hline & 3. Translation initiation factor (infE) & $\begin{array}{l}\text { Protects of tRNA from } \\
\text { hydrolysis }\end{array}$ & $5.2 / 77$ & NP_371619 \\
\hline \multirow[t]{5}{*}{ b8 } & 1. Formate acetytansferase & Anaerobic glycolysis & 52184 & NP_370750 \\
\hline & 2. CIpB chaperone-like protein & Stress proteins & $4 \_2 / 98$ & NP_371499 \\
\hline & 3. Translation initiation factor IF-2 & Translation & $5.0 / 17$ & NP_371793 \\
\hline & 4. Trigger factor & Promotes protein folding & 4.248 & NP_372199 \\
\hline & $\begin{array}{l}\text { 5. Branched-chain alpha-keto acid dehydrogenase } \\
\text { subunit E2 }\end{array}$ & $\begin{array}{l}\text { Carbohydrate } \\
\text { metabolism }\end{array}$ & $4.8 / 46$ & NP_371619 \\
\hline \multirow[t]{4}{*}{ b9 } & $\begin{array}{l}\text { 1. A Chain A, Crystal Structure At 2.7a Resolution Of A } \\
\text { Complex }\end{array}$ & $\begin{array}{l}\text { Binding as a protein } \\
\text { complex }\end{array}$ & $8.0 / 23$ & 1DEE_A \\
\hline & $\begin{array}{c}\text { Between A Staphylococcus Aureus Domain And A Fab } \\
\text { Fragment Of A }\end{array}$ & & & \\
\hline & Human lgm Antibody & & & \\
\hline & 2. $50 \mathrm{~s}$ ribosomal protein & Expression of mRNA & 9_5/24 & NP_371062 \\
\hline \multirow[t]{6}{*}{ b10 } & 1. Triosephosphate isomerase & Glycolysis & 4.7125 & NP_371298 \\
\hline & 2. Purine nucleoside phosphorylase & Purine metabolism & $43 / 26$ & NP_372662 \\
\hline & 3. Deoxyribose-phosphate aldolase & $\begin{array}{l}\text { Pentose phosphate } \\
\text { pathway }\end{array}$ & $4.5 / 23$ & NP_370662 \\
\hline & $\begin{array}{l}\text { 4_Phosphoribosylaminoimidazole-succinocarboxamide } \\
\text { synthase }\end{array}$ & Purine metabolism & $5.2 / 26$ & NP_371590 \\
\hline & 5. Putative translaldolase & $\begin{array}{l}\text { Carbohydrate } \\
\text { metabolism }\end{array}$ & $5.6 / 26$ & NP_6465,38 \\
\hline & $\begin{array}{l}\text { 6. A Chain A, Crystal Structure At 2.7a Resolution Of A } \\
\text { Complex }\end{array}$ & $\begin{array}{l}\text { Binding as a protein } \\
\text { complex }\end{array}$ & $8.0 / 23$ & 1DEE_A \\
\hline
\end{tabular}




\section{Serum proteins in bacterial surface}

We identified two serum proteins, apolipoprotein and globulin ( $\mathrm{Fc}$ and $\mathrm{Fab}$ ), in the membrane fraction of bacterial proteins. These results were confirmed from both 1D and 2-DE SDS PAGE. The presence of serum proteins in membrane fraction of bacterial protein has raised several questions. If we consider these proteins as a contaminant from the serum, why were we unable to wash out these proteins while we successfully washed out the most abundant serum protein such as albumin? If not a contaminant, what is causing these proteins to remain attached to the bacterial surface? It is known that Fc and Fab motifs of globulin interact with Spa C and Spa D domains of protein A. But the bacterial strain we used was a mutant of proteins A. In addition, by using a deletion mutant of Newman, we confirmed the presence of Fc and Fab with bacterial membrane associated protein (Figure 3). This raise another question of what components of bacteria are causing this Fc and Fab to remain attached with bacterial proteins.

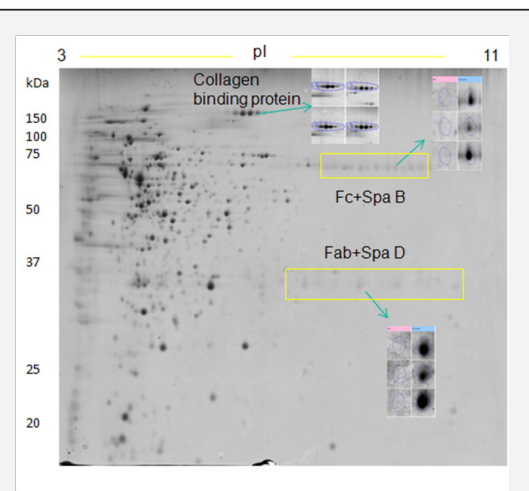

Figure 3: 2DE gel image of Staphylococcus aureus . Membrane protein fraction of bacteria grown in shake flasks was extracted by digesting with lysostaphin in presence of raffinose. Proteins shown on the gel were differentially expressed and identified by LC ESI MS. The in-set images show differentially protein expression in different biological replicates.

\section{Conclusion}

Polysaccharide intercellular adhesins production was significantly increased due to the addition of blood serum in the media. We identified two serum proteins, apolipoprotein and globulin ( $\mathrm{Fc}$ and $\mathrm{Fab}$ ), remained attached with the membrane fraction of bacterial proteins even after several washing procedures, indicating that these proteins might play a critical role in bacterial processes of biofilm formation.

\section{Author's contributions}

Nazrul Islam designed and conducted the experiment, and corresponding author for this manuscript. Julia M. Ross, Khwaja G. Hossain and Mark R. Marten developed the concept.

\section{Acknowledgment}

This research was supported by Grant no. R01AI059369 from the NIH and also an Institutional Development Award (IDeA) under NIH grant no. P20GM103442.

\section{References}

1. Costerton JW (1995) Overview of microbial biofilms. J Ind Microbiol 15(3): 137-140

2. Balzer M, Witt N, Flemming HC, Winqender J (2010) Faecal indicator bacteria in river biofilms. Water Sci Technol 61(5): 1105-1111.

3. Flemming HC, Winqender J (2010) The biofilm matrix. Nat Rev Microbiol 8(9): 623-633.

4. Mack D, Fischer W, Krokotsch A, Leopold K, Hartmann R, et al. (1996) The intercellular adhesin involved in biofilm accumulation of Staphylococcus epidermidis is a linear beta-1,6-linked glucosaminoglycan: purification and structural analysis. J Bacteriol 178(1): 175-183.

5. Chen J, Fallarero A, Maattanen A, Sandberg M, Peltonen J, et al. (2008) Living cells of Staphylococcus aureus immobilized onto the capillary surface in electrochromatography: a tool for screening of biofilms. Anal Chem 80(13): 5103-5109.

6. Floyd KA, Moore JL, Eberly AR, Good JA, Shaffer CL, et al. (2015) Adhesive fiber stratification in uropathogenic Escherichia coli biofilms unveils oxygen-mediated control of type 1 pili. PLoS Pathog 11(3): e1004697.

7. Wilson MM, Anderson DE, Bernstein HD (2015) Analysis of the outer membrane proteome and secretome of Bacteroides fragilis reveals a multiplicity of secretion mechanisms. PLoS One 10(2): e0117732.

8. Li M, Rosenshine I, Tung SL, Wang XH, Friedberg D, et al. (2004) Comparative proteomic analysis of extracellular proteins of enterohemorrhagic and enteropathogenic Escherichia coli strains and their ihf and ler mutants. Appl Environ Microbiol 70(9): 5274-5282.

9. Nandakumar MP, Cheung A, Marten MR (2006) Proteomic analysis of extracellular proteins from Escherichia coli W3110. J Proteome Res 5(5): 1155-1161.

10. Xia XX, Han MJ, Lee SY, Yoo JS (2008) Comparison of the extracellular proteomes of Escherichia coli B and K-12 strains during high cell density cultivation. Proteomics 8(10): 2089-2103.

11. Gerke C, Kraft A, Süssmuth R, Schweitzer O, Götz F (1998) Characterization of the $\mathrm{N}$-acetylglucosaminyltransferase activity involved in the biosynthesis of the Staphylococcus epidermidis polysaccharide intercellular adhesin. J Biol Chem 273(29): 1858618593.

12. Dubois M, A GK, Hamilton JK, Rebers PA, Smith F (1956) Colorimetric Method for Determination of Sugars and Related Substances. Analytical Chemistry 28(3): 350-356.

13. Islam N, Ross JM, Marten MR (2015) Proteome Analyses of Biofilm at Elevated Levels of NaCl. Clin Microbiol 4(5): 219.

14. Maira Litrán, Kropec TA, Abeygunawardana C, Joyce J, Mark G (2002) Immunochemical properties of the staphylococcal poly-Nacetylglucosamine surface polysaccharide. Infect Immun 70(8): 44334440 .

15. Götz F (2002) Staphylococcus and biofilms. Mol Microbiol 43(6):13671378.

16. Vuong C, Kocianova S, Voyich J, Yao Y, Fischer E, et al. (2004) A crucial role for exopolysaccharide modification in bacterial biofilm formation, immune evasion, and virulence. J Biol Chem 279(52): 54881-54886.

17. Conlon K, Humphreys H, O'Gara J (2002) icaR encodes a transcriptional repressor involved in environmental regulation of ica operon expression and biofilm formation in Staphylococcus epidermidis. J Bacteriol 184(16): 4400-4408.

18. Conlon K, Humphreys H, O'Gara J (2002) Regulation of icaR gene expression in Staphylococcus epidermidis. FEMS Microbiol Lett 216: 171-177. 
19. Conlon K, Humphreys H, O'Gara J (2004) Inactivations of rsbU and sarA by IS256 represent novel mechanisms of biofilm phenotypic variation in Staphylococcus epidermidis. J Bacteriol 186: 6208-6219.
20. Mah TF, O'Toole GA (2001) Mechanisms of biofilm resistance to antimicrobial agents. Trends Microbiol 9: 34-39.

This work is licensed under Creative Commons Attribution 4.0 Licens

DOI: 10.19080/AIBM.2017.02.555589

\section{Your next submission with Juniper Publishers} will reach you the below assets

- Quality Editorial service

- Swift Peer Review

- Reprints availability

- E-prints Service

- Manuscript Podcast for convenient understanding

- Global attainment for your research

- Manuscript accessibility in different formats ( Pdf, E-pub, Full Text, Audio)

- Unceasing customer service

Track the below URL for one-step submission https://juniperpublishers.com/online-submission.php 